\title{
Wokół problematyki genezy w Czekając na Godota Samuela Becketta
}

Dwutomowe wydanie dzieł Samuela Becketta w przekładzie Antoniego Libery, które ukazało się nakładem Państwowego Instytutu Wydawniczego, ${ }^{1}$ zachęca do odświeżenia znajomości tekstów Irlandczyka oraz do ponownej refleksji nad nimi. Zresztą powodów, by to uczynić, było w ostatnim czasie więcej w roku 2015 ukazała się książka-dialog Libery z dominikaninem o. Januszem Pydą. ${ }^{2}$ Jej lektura pozwala na poznanie myśli Becketta zawartych w wybranych dramatach i na skonfrontowanie ich z teologią chrześcijańską, co prowadzi niejednokrotnie do bardzo ciekawych spostrzeżeń.

Nazwisko ucznia Jamesa Joyce'a w obiegowej opinii kojarzy się zwykle z jednym tylko utworem, z tragikomedią Czekając na Godota, która na dodatek często pozbawiana jest swej głębi znaczeniowej na rzecz prostej konstatacji, że oto tytułowy Godot to Bóg, a główne postaci po prostu Nań czekają. ${ }^{3}$ Bar-

Mgr Piotr PaŁac - Uniwersytet Zielonogórski, e-mail: piotr1p@poczta.onet.pl.

(C) Copyright by Piotr Pałac \& Filozoficzne Aspekty Genezy.

${ }^{1}$ Por. Samuel Bескетт, Utwory wybrane w przekładzie Antoniego Libery. Tom 1: dramaty, sluchowiska, scenariusze, Państwowy Instytut Wydawniczy, Warszawa 2017; Samuel BeCKeTt, Utwory wybrane w przekładzie Antoniego Libery. Tom 2: eseje, proza, wiersze, Państwowy Instytut Wydawniczy, Warszawa 2017.

${ }^{2}$ Por. Antoni Libera i Janusz Pyda OP, Jesteście na Ziemi, na to rady nie ma! Dialogi o teatrze Samuela Becketta, Fundacja Dominikańskie Studium Filozofii i Teologii, Kraków 2015. Najnowsze wydanie ukazało się w roku 2018 nakładem Państwowego Instytutu Wydawniczego.

${ }^{3}$ Por. Marek KęDzIerski, Samuel Beckett, Wiedza Powszechna, Warszawa 1990, s. 370-375; Antoni Libera, „Wstęp”, w: Samuel Beckett, Dramaty, przeł. Antoni Libera, Zakład Narodowy im. Ossolińskich, Wrocław - Warszawa - Kraków 1999, s. XXXVIII-XL. Autorzy wymieniają wszystkie możliwości interpretacyjne związane z tajemniczym Godotem, przytaczają też anegdoty związane z wyborem takiego imienia. 
dziej kompetentny odbiorca połączy tekst Becketta $z$ teatrem absurdu i odnajdzie w sztuce - w układzie scenicznym, zachowaniu oraz kwestiach postaci cechy wyróżniające tego ważnego nurtu w dramaturgii dwudziestego wieku.

Warto przypomnieć najważniejsze myśli zawarte w najbardziej znanym utworze Becketta, tym bardziej, że wyniósł go na szczyty literackiego Parnasu, przynosząc Nagrodę Nobla. Jego problematyka, dzięki charakterystycznemu dla pisarstwa autora Końcówki uogólnieniu, jest wciąż aktualna, a bogactwo formalne i znaczeniowe dramatu otwiera możliwość wielokierunkowej interpretacji.

Godot to dzieło pansemiotyczne, można je ujmować na różne sposoby na przykład badać jego muzyczność, szukać w nim śladów biografii pisarza, dokonywać obrachunku z wiekiem dwudziestym, badać zależności intertekstualne, teologiczne i filozoficzne, można by wreszcie też, przechodząc na grunt ściśle polski, porównać dwa przekłady, Juliana Rogozińskiego i Libery, wskazując konsekwencje różnych lekcji tłumaczenia dla recepcji, rozumienia całości oraz inscenizacji teatralnych.

Ambicje tego szkicu są skromniejsze, zawarte tu rozważania skupiają się na problemie pojęcia genezy w dramacie Becketta. Gdy mowa o powstawaniu dzieła literackiego, odwołujemy się do całej gamy czynników go konstytuujących. Należy wziąć pod uwagę aspekt biograficzny, a więc wiek pisarza, czas i miejsce spisywania historii oraz jego wcześniejszą twórczość, i to zarówno teksty krytyczne, jak i beletrystykę oraz inne źródła, w których pojawiają się ślady myśli wyrażonych $w$ badanym dziele. $Z$ badaniem genezy utworu wiąże się również poszukiwanie wpływów filozoficznych, religijnych, literackich czy, szerzej, estetycznych, które przyczynily się do ukształtowania danego utworu. Mielibyśmy tedy do czynienia $\mathrm{z}$ genezą $\mathrm{w}$ sensie podstawowym, prymarnym, teoretycznoliterackim. Odnalezienie i uwzględnienie w interpretacji wyżej wymienionych kontekstów pozwoliłoby zrekonstruować genezę w sensie formalnym, odnoszącą się do powstawania dzieła literackiego. Na tym jednak nie koniec. W przypadku Czekając na Godota można też mówić o innego typu genezie, wynikającej z rozumienia myśli zawartej w dramacie. Innymi słowy, tekst Becketta daje odpowiedź na pytanie o okoliczności jego powstania, a także mówi coś ważnego na temat ludzkości. Tego rodzaju geneza wynika z interpretacji treści. 
Reasumując, mamy tu do czynienia $\mathrm{z}$ dwoma rodzajami genezy, które w przypadku tekstu Becketta są ze sobą ściśle związane, można rzec - wynikają jeden $\mathrm{z}$ drugiego, co znajduje odbicie $\mathrm{w}$ formalnym ukształtowaniu tragikomedii.

Zanim przejdziemy do ich omówienia, przypomnijmy pokrótce fabułę omawianego utworu, co pozwoli wprowadzić w temat niniejszego szkicu. Dramat Becketta, powstały w języku francuskim w roku 1948, a następnie przełożony przez niego samego na języka angielski, składa się z dwóch aktów. W obu występują Estragon i Vladimir oraz Pozzo i Lucky. Druga para bohaterów zjawia się na scenie tylko na chwilę, dzieląc poszczególne akty na części: przed ich przyjściem, z nimi na scenie oraz po ich wyruszeniu w dalszą drogę.

Estragon i Vladimir pojawiają się wieczorem w tym samym miejscu. $Z$ tekstu jasno wynika, iż znają to miejsce od dawna, a w każdym razie nie jest to ich pierwsze spotkanie. Witają się, rozmawiają o czasie spędzonym przed przyjściem, często się sprzeczają, czekają na Godota, który ma odmienić ich los. W międzyczasie Estragon walczy z butem, Vladimir uderza w dno kapelusza, wspominają przeszłość, grożą sobie odejściem od siebie, myślą o samobójstwie, dziwią się na widok egzotycznej pary Pozza i Lucky’ego, który jest prowadzony na sznurze przez pierwszego jak niewolnik. Estragon i Vladimir wysłuchują monologu tego drugiego. W końcu, po ich odejściu, nadchodzi Chłopiec, który informuje, że Godot dziś nie przyjdzie, zapewnia ich jednak, że zrobi to jutro. Zapada noc, wschodzi księżyc, postaci mówią o odejściu, lecz stoją nieruchomo na scenie.

$\mathrm{W}$ akcie drugim, ${ }^{4}$ choć z mniej lub bardziej drobnymi zmianami, schemat powtarza się: przywitanie, rozmowa o rozdzieleniu się, o pobiciu, rozmowy dla zabicia czasu, wielokrotne wspomnienie Godota, nadejście zmroku, spotkanie z Pozzem i Luckym, wizyta Chłopca-brata bliźniaka Chłopca z dnia poprzedniego, zapowiedź odejścia z jednoczesnym pozostaniem na miejscu.

\section{Geneza Czekając na Godota jako tekstu literackiego}

Aby wskazać genezę powstania dramatu, należy odwołać się do biografii Becketta, do inspiracji filozoficznych, religijnych i literackich oraz do wcze-

\footnotetext{
${ }^{4} \mathrm{O}$ różnicach między dwoma aktami będzie mowa niżej.
} 
śniejszego dorobku pisarza. ${ }^{5}$ Autor Nienazywalnego w czasie II wojny światowej, z racji tego, iż należał do Ruchu Oporu, ukrywał się na południu Francji, pracując u pewnego właściciela winnicy. W dramacie pada nazwa departamentu (Vaucluse), nazwa miejscowości (Roussillon) oraz nazwisko owego właściciela (Bonnelly):

VLADIMIR Mimo wszystko nie powiesz mi jednak, że to (gest) przypomina Vaucluse! Jest jednak duża różnica.

ESTRAGON Vaucluse! Jakie Vaucluse?

$[\ldots]$

VLADIMIR A jednak byliśmy tam razem, głowę dam za to. Pracowaliśmy przy winobraniu, u takiego jednego, co się nazywał... (strzela palcami) no, nie mogę sobie przypomnieć nazwiska... no tam, wiesz... (strzela palcami) nie mogę sobie przypomnieć nazwy... nie pamiętasz?

ESTRAGON (spokojniej) Może. Nic mi nie świta.

VLADIMIR Tam, niżej, wszystko było czerwone! ${ }^{6}$

Nadto drzewo obecne na scenie to wierzba. W starożytności sadzono je koło winnic, sądzono, że posiada ono dobry wpływ na dojrzewanie winogron, było również przydatne z powodu giętkich gałązek - służyły do podwiązywania winnej latorośli. ${ }^{7}$ Być może taka wierzba rosła koło winnicy, w której pracował Beckett. Wiejski pejzaż, na który składają się droga, rów, drzewo, kamień, niebo podczas zachodu oraz księżycowa noc, również mogą mieć swe źródło w pobycie w Roussillon w czasie wojny i wędrówkach po okolicy. Dodatkowo Estragon pyta, na kogo miałaby krzyczeć zbliżająca się postać: „Na konia”, odpowiada Vladimir; ${ }^{8}$ Pozzo powozi Luckym: „Wio!”, krzyczy pierwszy na drugiego,

\footnotetext{
${ }^{5}$ Por. KęDzierski, Samuel Beckett..., s. 370-400. Badacz wskazuje zależności dramatu od wcześniejszych utworów Becketta.

${ }^{6}$ Samuel Bескетт, Czekając na Godota, w: Вескетт, Utwory wybrane w przekładzie Antoniego Libery. Tom 1..., s. 65 [11-101]. Wszystkie nazwy padają tylko w wersji francuskiej. W wersji angielskiej - samo Vaucluse. Por. także przypis thumacza do kwestii Vladimira na temat czerwonego koloru ziemi.

${ }^{7}$ Por. Dorothea Forstner OSB, Świat symboliki chrześcijańskiej. Leksykon, przeł. Wanda Zarzewska, Paweł Pachciarek i Ryszard Turzyński, Instytut Wydawniczy PAX, Warszawa 2001, s. $178-180$

${ }^{8}$ Beскетt, Czekając na Godota..., s. 22-23.
} 
strzela batem. ${ }^{9}$ Lektura dramatu nie pozostawia wątpliwości - mamy do czynienia $\mathrm{z}$ pejzażem wiejskim, miejsce to można wskazać na mapie Francji, z dużą dozą prawdopodobieństwa można też stwierdzić, że to ono posłużyło autorowi do zbudowania przestrzeni scenicznej tekstu.

Wpływ na powstanie dramatu miały również inspiracje filozoficzne. W tekście widoczne są bezpośrednie odwołania do filozofii, często przekształcone i zaprawione humorem. Już na początku czytamy słowa Vladimira skierowane do Estragona: „Więc znowu jesteś”, na co ten odpowiada: „Myślisz?”. To, naturalnie, wymiana zdań odnosząca się do słynnych słów Kartezjusza. Beckett uważnie czytał dzieła autora Rozprawy o metodzie, jego dualizm często powraca w utworach Irlandczyka. Dwaj główni bohaterowie obsesyjnie boją się swego nieistnienia, życie zdaje się tylko snem, pragną być, najprawdopodobniej to właśnie z tego powodu przywołano myśl Kartezjusza, to echo jego eksperymentu myślowego. Pod koniec pierwszego aktu, w słynnym monologu Lucky'ego pojawia się nazwisko Woltera, ${ }^{10}$ uosabiającego ten nurt w filozofii, który zmienił perspektywę poznawczą, czyniąc z człowieka, z jego poznającego umysłu, a nie przedmiotów, centrum. Ludzkość zaczęła wówczas tracić wiarę w fundamentalne prawdy, pewniki, które objaśniały porządek świata. ${ }^{11}$ Apogeum tego procesu przypadło na wiek dwudziesty. Tłumacz, w przypisie ósmym do pierwszego aktu, zauważa, że akcja dramatu rozgrywa się najprawdopodobniej w latach czterdziestych tegoż wieku. Wyjaśnienie to dołączone jest do dość zaskakujących słów Vladimira: „[...] dlaczego akurat teraz upadać na duchu? Trzeba było o tym [rozstaniu] pomyśleć z milion lat temu, przed tysiąc dziewięćsetnym". ${ }^{12}$ Skoro więc akcja rozgrywa się w latach czterdziestych, to dlaczego „przed tysiąc dziewięćsetnym” to „milion lat temu”? Być może chodzi tu o przyspieszenie rozwoju ludzkości oraz o konsekwencje procesu myślowego rozpoczętego przez wspomnianych Kartezjusza, Woltera, przez Spinozę, Berke-

\footnotetext{
${ }^{9}$ Bескетт, Czekając na Godota..., s. 25. Całe zachowanie Pozza względem Lucky’ego przypomina relacje (w tym wypadku — wypaczone) właściciela z posiadanym zwierzęciem.

${ }^{10} \mathrm{~W}$ wersji angielskiej dramatu pada nazwisko Berkeleya (por. przyp. 88 na s. 430 do pierw szego aktu Czekając na Godota).

${ }^{11}$ Por. Libera i Pyda, Jesteście na Ziemi..., s. 29-33. Jak zaznacza Libera, Beckett nie ocenia tej zmiany, stwierdza jedynie, że tak się stało, że wpłynęło to na dalsze losy człowieka, który nie jest szczęśliwy.

${ }^{12}$ Beckett, Czekając na Godota..., s. 12.
} 
leya, Kanta i Schopenhauera, co z kolei, jako duchowe dziedzictwo, znalazło wyraz w teorii ewolucji, psychoanalizie i teorii względności. ${ }^{13}$ Człowiek stanowi o sobie samym, lecz jednocześnie stracił wiarę, „skurczył się” — jak stwierdził w swym monologu-parodii języka naukowego Lucky.

W akcie drugim padają słynne słowa „Nie wchodzi się nigdy dwa razy w to samo gówno". To ironiczne nawiązanie do Heraklita z Efezu jest jednocześnie wyrazem ogólnej myśli zawartej w tekście, a dotyczącej upływu czasu. ${ }^{14}$ Niszczy on ludzkość jako gatunek i jako jednostkę, co znajduje wyraz w subtelnych, lecz wyraźnych różnicach pomiędzy dwoma aktami tragikomedii. ${ }^{15}$

Ważne wydaje się także nawiązanie - nie wyrażone explicite w tekście do poglądów Giambattisty Vico, który, wypowiadając się w swojej Nauce nowej na temat rozwoju ludzkości i rozwoju społecznego, dzielił je na trzy etapy, trzy epoki, które następują po sobie w linii spiralnej. Tymi fazami są: epoka bogów, epoka bohaterów i epoka ludzi. Odpowiadają im trzy instytucje: Religii, Małżeństwa i Pogrzebania oraz abstrakcyjne: Narodziny, Dojrzałość i Zepsucie. Znajduje to też odbicie w klasyfikacji języka na Hieroglificzny, inaczej sakralny, Metaforyczny, czyli poetycki i Filozoficzny, pełen abstrakcji i uogólnień. Po epoce ludzi następuje ricorso, powrót do epoki pierwszej, lecz na wyższym poziomie. Czas w tej koncepcji jest kolisty, nie linearny. ${ }^{16} \mathrm{~W}$ kontekście omawianego dzieła kluczowa okazuje się trzecia $\mathrm{z}$ tych epok. W niej człowiek zdobywa pełnię samowiedzy o sobie, staje się niezależny, nie wierzy w wyjaśnienia na temat świata proponowane w poprzednich epokach. Koresponduje to z wcześniejszą refleksją na temat Woltera i wymienionych filozofów, którzy w bezpośredni lub pośredni sposób wpłynęli na przełom w myśleniu, mający swoje apogeum w wieku dwudziestym. W dramacie wciąż wspomina się o samotności, braku pocieszenia, czekaniu. Najpełniej wyraża to monolog Lucky'ego, stylizowany na język naukowy. Przywołuje on wyniki badań, padają nazwiska naukowców,

\footnotetext{
${ }^{13}$ Por. Libera i Pyda, Jesteście na Ziemi..., s. 30.

${ }^{14}$ Por. Libera, „Wstęp...”, s. XXX-XXXIII.

${ }^{15}$ Najwyraźniej zaznacza się to w kondycji Pozza i Lucky'ego: pierwszy w drugim akcie jest niewidomy, a drugi - niemy; różnice między aktami wymienia Libera (por. LiBerA, „Wstęp...”, s. L-LI).

${ }^{16}$ Por. Samuel Beckett, „Dante... Bruno. Vico... Joyce”, w: Samuel Beckett, Wierność przegranej, przeł. Antoni Libera, Znak, Kraków 1999, s. 6-17; Antoni LiBerA, „Posłowie”, w: BECKETT, Wierność przegranej..., s. 128-133.
} 
Lucky jąka się, deprecjonując w ten sposób wartość tego, co mówi. Zostaje również wyrażona myśl na temat człowieka, który, pomimo wszechstronnego rozwoju, „marnieje i usycha”, „usycha i kurczy się”. ${ }^{17}$ Filozofia pozwoliła człowiekowi na oddzielenie od bezrefleksyjnej natury, dała mu kulturę, dzięki której może tworzyć, może poczuć się kimś więcej niż zwierzęta, jednocześnie zaś traci szczęście, czuje się wyobcowany.

W Czekając na Godota pojawia się również szereg odwołań literackich, które miały wpływ na genezę powstania dramatu. Do najważniejszych z nich należą aluzje lub cytaty z Biblii, zarówno Starego, jak i Nowego Testamentu, oraz nawiązania do utworu Pedra Calderona Życie jest snem.

Beckett, podobnie jak jego mistrz Joyce, przykładał wielką wagę do formy dzieła literackiego. Miało ono znaczyć nie tylko poprzez warstwę leksykalną, lecz także poprzez ukształtowanie formalne innych poziomów dzieła. Dochodzimy tym samym do fascynacji Becketta sentencją Świętego Augustyna, który napisał w Wyznaniach na temat ukrzyżowanego Jezusa oraz łotrów: „Nie rozpaczaj: jeden z łotrów został zbawiony. Nie pozwalaj sobie: jeden z łotrów został potępiony", co odnosi się do Łk 23:39-43. Najważniejsza jest tu, zaznaczmy od razu, fascynacja formą, symetrią, układem $2+1$ : dwa elementy i trzeci z nich wynikający. To, naturalnie, elementy stosowanej często przez Becketta kompozycji liczbowej dzieła literackiego, której początki można zauważyć już w starożytności. Liczba liter alfabetu greckiego wpłynęła na dokonany przez filologów aleksandryjskich podział Iliady oraz Odysei na 12 ksiąg każda. Źródłem symboliki liczb była filozofia Pitagorasa, rozwinięta później przez jego uczniów, a w średniowieczu wzmocniona chrześcijańskim symbolizmem liczbowym. W epoce tej niezwykłą popularnością cieszył się jeden werset z Księgi Mądrości (11:20): omnia in mensura et numero et pondere disposuisti [,,aleś Ty wszystko urządził według miary i liczby, i wagi!”]. „Idea ordo w średniowiecznym obrazie świata wywodzi się właśnie z tego jednego wersetu Biblii”. ${ }^{18}$ Bóg stworzył świat, kierując się określonym planem, a liczba stała się „czynnikiem nadającym for-

\footnotetext{
${ }^{17}$ BeскетT, Czekając na Godota..., s. 47-48.

${ }^{18}$ Ernst Robert CURTIUs, Literatura europejska i lacińskie średniowiecze, przeł. Andrzej Borowski, Universitas, Kraków 1997, s. 530. Rozdział, z którego pochodzi ten cytat, w całości poświęcony jest zagadnieniu kompozycji liczbowej. Autor podaje wiele ciekawych przykładów utworów literackich budowanych na bazie określonych liczb.
} 
mę". ${ }^{19}$ Zaczęły więc powstawać dzieła, których forma (liczba wersów, strof oraz innych jednostek konstrukcyjnych) wyrażała ów porządek stworzonego świata poprzez język liczb. Libera dokonał imponującego zestawienia zabawy Becketta formą. Budowa oraz inne elementy znaczące Czekając na Godota oparte są na wzorze „2+1”, dominują „dwójka” i „trójka”. Oto wybrane przykłady: ${ }^{20}$

— Czekając na Godota składa się z dwóch aktów, każdy z nich zbudowany jest, o czym była już mowa, z trzech części;

— w dramacie występują dwie pary bohaterów, Estragon i Vladimir, dopełnieni w obu aktach przez Chłopca (trzeci element);

- Chłopców jest dwóch (bracia bliźniacy), a pracują oni dla kogoś trzeciego, czyli Godota;

— na scenie obecne są dwa elementy świata przyrody - roślina, drzewo, wierzba (przyroda ożywiona) oraz kamień (przyroda nieożywiona), dwa elementy plus trzeci - człowiek, odróżniający się od reszty swoją zdolnością myślenia i tworzenia;

— na scenie obecne są dwa obiekty: kamień i drzewo oraz element trzeci droga, metafora wędrówki człowieka;

- występują dwie postaci, z racji tego, iż sentencja Augustyna nawiązuje do sceny ukrzyżowania, trzy razy stoją łącznie na trzech nogach;

- Vladimir proponuje Estragonowi trzy rodzaje pożywienia, w sumie w tekście je on dwa razy, wybiera dwa rodzaje posiłków, ale spożywa tylko element trzeci - marchewkę;

— Estragon i Vladimir, czyli dwaj bohaterowie, podtrzymują w obu aktach trzecią postać (w I akcie był to Lucky, w II akcie - Pozzo), co z kolei przypomina trzy krzyże na Golgocie.

To rzadko spotykana koncepcja kompozycyjna: forma dzieła literackiego jest podporządkowana treści. Gdyby Beckett nie przeczytał Wyznań Augusty-

\footnotetext{
${ }^{19}$ CURTIUS, Literatura europejska..., s. 531.

${ }^{20}$ Por. Libera, „Wstęp...”, s. XLIII-XLV.
} 
na, nie byłoby Godota w takim kształcie, w jakim możemy go dziś poznać. To kluczowa inspiracja mająca ogromny wpływ na genezę powstania tego dramatu.

\section{Geneza czlowieka i istoty boskiej w Czekając na Godota}

Inspiracja Świętym z Hippony nie kończy się tylko na formie. Beckett idzie dalej, łączy plan wyrażania z planem treści. Wzór „2+1”, a tym samym przypisanie szczególnej roli „dwójce” i „trójce”, można także odnieść do historii gatunku ludzkiego. W jaki sposób pisarz dokonał tego połączenia? Aby odpowiedzieć na to pytanie, należy dokonać analizy formalnej imion postaci. Czytelnik ujrzy wówczas — jeszcze raz — symetrię Augustyna:

Estragon — osiem liter — trzy sylaby;

Vladimir — osiem liter — trzy sylaby.

Inna (druga, zdrobniała) wersja imienia:

Estragon: Gogo — cztery litery — dwie sylaby — każda sylaba składa się $\mathrm{z} d$ wóch liter;

Vladimir: Didi — cztery litery — dwie sylaby — każda sylaba składa się $\mathrm{z} d$ wóch liter

(dwie pary postaci, każda z nich zostaje dopełniona trzecim elementem: Estragon i Vladimir - Chłopcem, ale także Godotem, na którego czekają, oraz Pozzem i Luckym, z którymi tworzą pełen obraz ludzkości; Pozzo i Lucky - Estragonem i Vladimirem).

Pozzo — pięć liter — dwie sylaby;

Lucky — pięć liter — dwie sylaby;

Godot — pięć liter — dwie sylaby.

Imię używane przez Chłopców w stosunku do Vladimira:

Albert — dwie sylaby. 
Dalej: imiona Godota i Pozza zostają przekręcone na $d w a$ sposoby: BozzoGozzo i Gobot-Godet, co razem z ich poprawnymi wersjami tworzy układ trójczłonowy: Pozzo-Bozzo-Gozzo, Godot-Gobot-Godet.

To forma, teraz jednak należy przyjrzeć się znaczeniu imion.

Imię Estragon, nie bez powodu wymieniane w niniejszym szkicu zawsze jako pierwsze, oznacza ziele, które pobudza apetyt. Forma zdrobniała — Gogo, czyli powtórzony dwukrotnie czasownik angielski ,iść”. Estragon jest kapryśny, ciągle głodny, prosi Vladimira o jedzenie, rzuca się na kości kurczaka zjedzonego przez Pozza, nadto często cierpi z powodu uciskającego buta, często też siada, jest zmęczony, myśli o spaniu, za pomoc udzieloną Pozzowi chce pieniędzy. Słowem - jest interesowny, skupiony na sobie; to ciało człowieka, to, co materialne, przyziemne, związane z popędami, naturą.

Vladimir, czyli ten, który „panuje nad światem”, w formie zdrobniałej Didi, od powtórzonego czasownika francuskiego dire, „mówić”, opiekuje się Estragonem, wiele razy podkreśla, że ten nie dałby rady bez niego, myśli, mówi, przejmuje się losem Lucky'ego, a więc nie myśli tylko o sobie — to umysł, intelekt, sfera duchowa człowieka, świat kultury.

Imię tytułowej postaci rzeczywiście może kojarzyć się z angielskim God, jednak w połączeniu $\mathrm{z}$ francuskim przyrostkiem -ot, biorąc jeszcze pod uwagę dwie wersje językowe sztuki, wymyka się jednoznacznej interpretacji. Na pewno upatrywanie w nim Boga jest uzasadnione, jednak tylko pod pewnymi warunkami.

Pozzo to „szambo”, a Lucky — „szczęściarz” lub ktoś, kto, poprzez odwołanie do pełnych wersji angielskich imion, czyli do Lukasza lub Lucjana, jest związany ze światłem.

To ważne objaśnienie ${ }^{21}$ pozwala lepiej zrozumieć drugie wspomniane na wstępie znaczenie pojęcia genezy — genezy rodzaju ludzkiego, a co za tym idzie: idei czekania oraz istoty boskiej.

Na początku był Estragon, bardzo samotny i nieszczęśliwy. Zaczął mówić. Żadna inna istota tego nie potrafi - tylko człowiek. W mówieniu tkwi, immanentnie, dialogiczność. Jest ten, kto mówi, oraz ten, kto słucha i odpowiada. Tak

${ }^{21}$ Por. Libera, ,Wstęp...”, s. XLIII-XLIV. 
powstał Vladimir, swoiste remedium na samotność, który z czasem stał się Rozumem, Intelektem. Środek uśmierzający samotność nie działał jednak zbyt długo, Estragon i wydzielony z niego Vladimir dalej byli samotni, ten ostatni więc musiał stworzyć kogoś niezależnego, transcendentnego, wykraczającego poza niego i świat. Powstała idea istoty boskiej, Godota, który odmieni los człowieka. Utwór Becketta nie traktuje jednak o Godocie, jego bowiem, jak na razie, nie ma. To tekst o czekaniu na niego, o kondycji ludzkiej w czasie czekania. $Z$ wypowiedzi postaci wynika, że kiedyś były szczęśliwe, pełne nadziei. Gdy zbliża się koniec aktu drugiego i Chłopiec mówi, że Godot i tym razem nie przyjdzie, Vladimir rzuca: „Chryste, zmiłuj się nad nami!” Vladimir zresztą przewiduje odpowiedzi Chłopca w drugim akcie, zupełnie tak, jakby wiedział, że Godot nie przyjdzie. Najprawdopodobniej nie przyjdzie dlatego, że nie istnieje, bo jest wymysłem wyrwanej przyrodzie przez filozofię i rozwój cywilizacji Ludzkości, która szuka większego znaczenia dla swojej egzystencji. ${ }^{22}$

$$
* * * * *
$$

Pisarstwo Samuela Becketta często jest charakteryzowane francuskim comment c'est, co znaczy ,jak jest”. Pisarz nie decyduje, nie rozstrzyga, przedstawia jedynie obraz tego, czego doświadcza on sam i ludzie na świecie wszystkich czasów. Przedstawiona w dramacie historia jest niezwykle prosta, to wzór. Nie odwołuje się do zagadnienia grzechu pierworodnego, jest niezależna od całej mitologii judeochrześcijańskiej, można wręcz zaryzykować stwierdzenie, że to idea Zbawiciela, Pocieszyciela zawarta w Starym i Nowym Testamencie, jest wyrazem ogólnej tęsknoty rodzaju ludzkiego, o której mowa w Czekając na Godota. Beckett odsłonił przed czytelnikiem mechanizm: samotność, poczucie wyobcowania, przerażenie spowodowane koniecznością śmierci kazały uwierzyć człowiekowi w ideę zbawienia, w możliwość odmiany losu. To było pierwsze, dopiero potem narodziła się religia $\mathrm{z}$ jej konkretnymi rozwiązaniami w tej materii.

Człowiek, żyjący w epoce ludzi, Pogrzebania-Zepsucia-Języka Filozoficznego, czyli w wieku dwudziestym, bogaty w doświadczenia minionych czasów, odkrywa prawdę o istnieniu: to czekanie na odmianę, wymyślone przez niego

\footnotetext{
${ }^{22}$ Całościowe omówienie problematyki Czekając na Godota znaleźć można w: LiBERA, „Wstęp...”, s. XXXVIII-LXII.
} 
samego lub objawione, lecz jednak czekanie, któremu towarzyszą samotność, zwątpienie, śmierć. O tym właśnie traktuje Czekając na Godota Becketta.

Piotr Pałac

\section{Bibliografia}

BеСКетт Samuel, Czekając na Godota, w: Beckett, Utwory wybrane w przekładzie Antoniego Libery. Tom 1..., s. 11-101.

BеСКетt Samuel, „Dante... Bruno. Vico... Joyce”, w: BeСKetт, Wierność przegranej..., s. 6-17.

Beckett Samuel, Dramaty, przeł. Antoni Libera, Zakład Narodowy im. Ossolińskich, Wrocław - Warszawa - Kraków 1999.

Bескетт Samuel, Utwory wybrane w przekładzie Antoniego Libery. Tom 1: dramaty, słuchowiska, scenariusze, Państwowy Instytut Wydawniczy, Warszawa 2017.

Bескетт Samuel, Utwory wybrane w przekladzie Antoniego Libery. Tom 2: eseje, proza, wiersze, Państwowy Instytut Wydawniczy, Warszawa 2017.

Bескетт Samuel, Wierność przegranej, przeł. Antoni Libera, Znak, Kraków 1999.

CURTIUS Ernst Robert, Literatura europejska i lacińskie średniowiecze, przeł. Andrzej Borowski, Universitas, Kraków 1997.

FoRSTNER Dorothea OSB, Świat symboliki chrześcijańskiej. Leksykon, przeł. Wanda Zarzewska, Paweł Pachciarek i Ryszard Turzyński, Instytut Wydawniczy PAX, Warszawa 2001.

KĘDZIERSKI Marek, Samuel Beckett, Wiedza Powszechna, Warszawa 1990.

Libera Antoni, „Posłowie”, w: Beckett, Wierność przegranej..., s. 128-133.

Libera Antoni, „Wstęp”, w: BeCKETt, Dramaty..., s. XXXVIII-XL.

LiBera Antoni i Pyda Janusz OP, Jesteście na Ziemi, na to rady nie ma! Dialogi o teatrze Samuela Becketta, Fundacja Dominikańskie Studium Filozofii i Teologii, Kraków 2015.

\section{Wokół problematyki genezy w Czekając na Godota Samuela Becketta}

\section{Streszczenie}

Szkic podejmuje problem genezy w Czekając na Godota Samuela Becketta.

W pierwszej części ukazano genezę w sensie formalnym. Wymieniono w niej czynniki, które wpłynęły na powstanie tragikomedii. Są to: aspekt biograficzny, związany z pobytem 
Becketta w czasie II wojny światowej na południu Francji oraz inspiracje kulturowe (filozoficzne, religijne i literackie). Fascynacja autora frazą z Wyznań Świętego Augustyna wpłynęła na płaszczyznę formalną utworu. Beckett zrealizował w nim ideę jedności formy i treści.

W dalszej części szkicu poruszono problem genezy rodzaju ludzkiego. Człowiek, od zarania dziejów samotny, dążył do odmiany losu. Wytworzył Rozum, Intelekt i rozpoczął dialog niwelujący samotność oraz rozpacz. Ten zabieg nie przyniósł spodziewanych efektów, dlatego też zrodziła się idea istoty transcendentnej wobec niego. Od tego momentu człowiek czeka na nią i na odmianę swego losu.

Słowa kluczowe: geneza, jedność formy i treści, Kartezjusz, Święty Augustyn, Giambattista Vico, dualizm, kompozycja liczbowa, samotność, czekanie.

\section{Elaborating Issues of Genesis in the Play Waiting for Godot by Samuel Beckett}

\section{Summary}

This sketch focuses on the problem of genesis as it figures in the play Waiting for Godot by Samuel Beckett.

The first part presents the notion of genesis in formal terms, listing the factors that had an influence on the emergence of the tragicomic in Beckett. These consist of a biographical aspect relating to his stay in the south of France during the Second World War, and some cultural inspirations of a philosophical, religious and literary sort. Beckett's fascination with a phrase deriving from the Confessions of Saint Augustine influenced the work from the point of view of its formal concerns, and acting under its influence, he sought to create a unity of form and content.

In the next part of the sketch, the issue of the genesis of mankind is raised. Humankind, afflicted by loneliness since the dawn of time, has sought to reverse this fate - by conceiving Reason and Intellect, and by starting a dialogue aimed at eliminating that very loneliness and despair. Yet this did not bring the expected results, so in response the idea of a transcendent being was created. Ever since that moment, humanity has found itself waiting for the latter to appear, and for the reversal of its fate that this was supposed to bring.

Keywords: genesis, unity of form and content, Descartes, Saint Augustine, Giambattista Vico, dualism, numerical composition, loneliness, waiting. 